\title{
FACTORS AFFECTING THE USE OF 4G SERVICES: THE CASE OF VIETNAM
}

\author{
Binh Tran Duy \\ Nguyen Tat Thanh University, Ho Chi Minh City, Vietnam \\ Tran Huu Ai \\ Van Hien University, Ho Chi Minh City, Vietnam
}

$4 G$ services open the door for conversation and data communications by means of high-speed mobile connection. However, the actual use of the $4 G$ speeds is still below expectations. Therefore, it is important to understand the interaction of factors involved in the adoption of this technology. Previous studies have shown that such variables as convenience, efficient service quality and variety of services, perceived value and price are important factors in the course of $4 G$ technology adoption. In this study, the authors examine the impact of these factors on own sample of the $4 G$ service users. Our research results demonstrate that: 1) price, convenience and varied services are important predictors of value perception; 2) there is a relationship between diversity of services and the sense of value mediated by convenience and 3) perceived value has a strong relationship with the intention to buy.

Keywords: 4G technology; convenience; diversity of services; perceived value; Vietnam.

\section{Introduction}

4G services as the fourth-generation cellular technology opens the door to high-speed communications for both people and data. Improved capabilities of $4 \mathrm{G}$ networks and devices in their combination with greater customer satisfaction together have made the usage of media much more attractive, thus quickly increasing the attractiveness of $4 \mathrm{G}$ services for

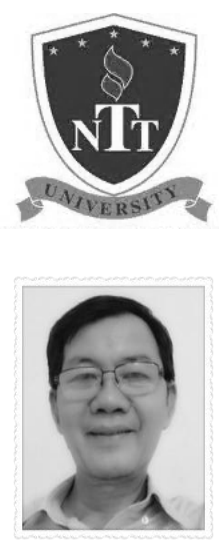

\section{Binh Tran Duy}

MA, Lecturer at Nguyen Tat Thanh University, Ho Chi Minh City, Vietnam

Research interests: SMEs functioning and government support, consumer behavior, innovative products markets and finances.

Email: tdbinh@ntt.edu.vn

Ai Tran Huu

$\mathrm{PhD}$, lecturer of Faculty of Economics, Van Hien University, Ho Chi Minh City, Vietnam

Research interests - markets of agricultural products, SMEs functioning and government support, organic food markets, ecological economics, environmental issues of economic development and corporate social responsibility

Published more than 50 papers in International journals, member of editorial board of International journals

E-mail: aith@vhu.edu.vn 
potential clients globalwide. 4G services offer a full-range access to music, videos and data services. This feature is seen as the key prospect for all service providers in most countries (Forrester Research, 2002; 4G UK, 2004; Garfield, 2004).

\section{Review of literature}

Most empirical studies on this topic have used innovation-oriented measures; acceptance is frequently specified as acquisition of innovation (Eichmann and Kemmerer, 1999) or as a commitment to apply it. The most widely adopted models in this context include: TAM (Technology Acceptance Model) derived from the theory of reasoned action (TRA), in particular, its version of computer usage behavior became quite popular (Davis et al., 1989). TAM is specifically planned for the users that adopt modeling information systems. It focuses on the attitude of ignoring subjective rules due to theoretical and psychological uncertainty (Davis et al., 1989). This model combines two beliefs of the acceptance of potential customers -- the perception of usefulness and the sense of technology used -- as the main determinants of attitudes towards a new technology. These two beliefs create a favorable or intentional orientation towards the role of information technology (IT), thus affecting indirectly its use (Davis et al., 1989).

TAM is an adaptation of the Theory of Reasoned Action (TRA) to the fields in which information systems (IS) are used most actively. TAM acknowledges that it is helpful and easy to identify individual intent to use a system with the aim of having it as an intermediary in a certain real-life arrangement. The perceived useful also be studied to immediately touch the feel of use. Researchers have previously simplified TAM by means of removing the constructive attitude found in TRA from the current specification (Venkatesh et al., 2003). Attempts to extend TAM are usually taken in one of the possible three ways: introducing elements from the relevant models; introducing additional or alternative beliefs; or examining premises and operating perceptions (useful and easy) in the course of using (Wixom and Todd, 2005).

\section{Observed variables}

Under the TAM model, the observed variables affect the acceptance of a technology. Trends (1979) stated that the facilitating variables, including the level and the type of support, are affecting both adoption and use of technologies by individuals. Venkatesh et al. (2003) stated in this regard the following: "Facilitating as such is the extent to which an individual believes that organizational and technical infrastructure exists to back up the function of the system". Several previous studies have suggested a number of variables to observe in the course of technology adoption (see the suggestions provided in (Legris Ingham and Collerette, 2003) for example). 
After examining the previous researches on the use of $4 \mathrm{G}$ services (Han, 2002; Pedersen and Ling, 2002; Pagani, 2004) we also would like to identify a group of observational variables that drive the acceptance of $4 \mathrm{G}$ services. Stemming from suitability of $4 \mathrm{G}$ technology, the following variables have been chosen: service quality, convenience, efficiency, and variety of services. Factors not included here directly but which are still part of general satisfaction are by default considered as part of convenience (Yale and Venkatesh, 1986).

\section{Convenience}

The 4G service today is taking technology to the next level of service provision which includes trouble-solving anytime and at anyplace. Convenience includes, inter alia, changeability which is understood here as access to information during the time of direct communication (Pagani, 2004). Convenience alone may be a necessary element in using 4G services, however, it is not enough, Ng-kruelle and her colleagues (2002) came to such a conclusion while analyzing the cost of convenience. In their discussion, privacy is often the price as today what is convenient in use often brings along the loss of freedom and privacy. For example, a $4 \mathrm{G}$ phone user may be uncomfortable using video phone features, when he or she is not properly dressed.

Yale and Venkatesh (1986) classified convenience into six measures: the time in use, location, fit, mobility, access and avoiding discomfort. However, Gehrt and Yale (1993) later argued that these types are not complete or enough. Building on their research and conclusions, Berry, Seiders and Grewal (2002) formulated their own five features of convenient services: convenient decision, convenient access, convenient transaction, convenient process of servicing and convenient after-sales service. These types reflect all the stages of consumer activity in the course of buying something or using some services. Consumers tend to have certain separate perceptions related to time, costs and efforts pertaining to each type of service and also each stage of being serviced. Together they define the overall convenience for consumers. In this study, we will be looking at $4 \mathrm{G}$ services as a service and technology at the same time, as opposed to a pure product.

\section{Quality of service}

Quality of service has been studied in many fields, including marketing, economics, consumer research, information systems and more. Service quality perception is defined as the customer's overall perception of service quality (Zeithaml, 1988). Consumer decision results, to some extent, mean comparing consumers' expectations and their perceptions of the actual service being performed (Lewis, 1989). Parasuraman et al. (1988) argued that the overall quality of customer service depends on how wide is the gap between these two. 


\section{FACTORS AFFECTING THE USE OF 4G}

Since the 1980s, SERVQUAL model (Parasuraman et al., 1988) has been widely used for consumer service evaluation. SERVQUAL, based on the unstable model, helps to analyze this gap between the performing quality of a servicing organization on the one hand and the service needs of the customers being serviced on the other. Despite the obvious usefulness of this model, it has been also widely criticized (see, for example, Brown et al., 1993; Buttle, 1996). In particular, SERVPERF has been offered as an alternative to measure the performance based solely on service quality as opposed to what is expected (purely cognitive element) (Cronin Jr. and Taylor, 1994).

In the context of $4 \mathrm{G}$ services, service quality includes availability of network, its reliability and accessibility. A user can also consider the level of functionality of both hardware and software, the size of devices, battery life, Internet speed, speed to downloads and installations, display screen and other functionality features provided (Pagani, 2004).

\section{Value}

Value has been defined in a variety of different ways. For example, according to (Zeithaml, 1988), meaningful value can be defined as follows: 1) Value is low when overall quality is low; 2) Value is what you want to get from a product you've purchased or service you are using; 3) value is the quality received according to the price paid and 4) value is what consumers are getting, what has been given to them. In much simpler terms, value is the difference between what is received and what has been given. Some studies have adopted the vision that value is a balance between benefits and sacrifices. The benefit components of value include prominent intrinsic attributes, external attributes, feeling the quality, and other high levels of abstraction can be also involved. The sacrificial components include price and non-monetary price. In this study, the authors use the definition from (Zeithaml, 1988). Perceived benefits can take the form of the products that are related to benefits (i.e., product quality) or transactional benefits (i.e., quality of service, time, and effort).

In the context of $4 \mathrm{G}$ services, transaction processes are as important as product quality. Clients accumulate information about a particular telecom company through the experience of dealing with this company. From the viewpoint of maximizing value (Kahneman and Tversky, 1979; Thaler, 1985; Zeithaml, 1988), customers are able to perform transactions that maximize benefits and minimize sacrifices. Perceived value has been proposed as a multidimensional structure. Kahneman and Tversky (1984) used to classify values as two different types: value experience and decision value. Sheth et al. (1991) proposed five value scales: functional, social, emotional, knowledge and conditional. Convenience includes six dimensions - time of use, location, fit, dynamic feature, access and avoiding discomfort (Yale and Venkatesh, 1986).

A variety of services will empower users perform more tasks. Many utilities will be implemented with only one integrated device, thus reducing the time and the effort required to make changes in functions. Thus, the greater is the variety of services offered by the 
technology, the more convenient it will be for all current and potential customers. Ng-Kruelle et al. (2002) also show that higher level of technology allows better problem-solving with 4G services, thus increasing their convenience, among other things. Thus, we formulate our hypothesis $\mathrm{H}$ as follows:

H1: Diversity (S1) offered by $4 G$ has its positive influence on the convenience of using $4 G$.

Functional value is the perceived utility acquired as a result from the ability to reach the goal through various functions (Sheth et al., 1991). Integrating more services into a single device, users get more benefits by using one and the same technology. Thus, the hypothesis $\mathrm{H} 2$ has been formulated as follows:

H2: Diversity (S2) offered by $4 G$ has its positive influence on the perceived value of using $4 G$.

Ng-Kruelle et al. (2002, p. 277) have provided quite exact definition for convenience: this is "how some operations are made easier." When a user feels that $4 \mathrm{G}$ service is providing convenience by reducing time and effort, it will impact the user's perception of the benefits provided by this service, thus also influencing the perception of price and value. Thus, the hypothesis $\mathrm{H} 3$ has been formulated as follows:

H3: Convenience (S3) has a positive impact on the value of using $4 G$.

Value experiences refer to the level of satisfaction, joy or sadness or frustration experienced through the course of being serviced (Kahneman and Tversky, 1984). Convenience of $4 \mathrm{G}$ will increase user satisfaction, thereby positively impacting the value experience. Similarly, service quality can be enhanced through valuable experience as well. Thus, the hypothesis $\mathrm{H} 4$ has been formulated as follows:

H4: Quality of service (S4) has a positive impact on the value of using $4 G$.

Value perception is derived from the comparison between objective price and the reference price (Thaler, 1985). Due to this negative impact of price perception, which serves as a sacrificial component, we recognize the negative relationship between price perception and perceived value. This negative relationship has been supported by several studies, including (Dodds et al., 1991; Teas and Agarwal, 2000; Chen and Dubinsky, 2003). Thus, high prices will lead to reducing value of the $4 \mathrm{G}$ services in the eyes of consumers. Thus, the hypothesis $\mathrm{H} 5$ has been formulated as follows:

H5: High prices (S5) negatively affect the value perceived from using $4 G$.

High value perception also implies high perception of benefits and sacrifices. From the perspective of maximizing value (Kahneman and Tversky, 1979; Thaler, 1985; Zeithaml, 1988) customers are able to perform transactions so that to maximize benefits and minimize 
sacrifice. Numerous studies show that perceived value is an important predictor of behavior (Bolton and Drew, 1991; Cronin et al., 2000). Thus, the hypothesis H6 is formulated as follows:

H6: Value perception (S6) influences positively the behavior of users through the process of using $4 G$.

\section{Research Methods}

The most commonly used method to consider customer satisfaction is the "Expectation Confirmation" theoretical framework. According to Oliver (1980), this theoretical connection is based on two small processes that have independent impact on customer satisfaction: anticipation of service prior to purchase and perception of service after it has been actually experienced. Applying this theory to the $4 \mathrm{G}$ services, it would be possible to understand customer satisfaction as a process as follows: firstly, the customer develops his/her thinking expectations about the components that make up the quality of a service that the supplier can deliver before the customer decides to buy. Then goes buying the service and using the service, both contributing (or not, in the most unfortunate cases) to customer trust in the true performance of the $4 \mathrm{G}$ service that they can feel is good or bad. Thus, survey would be probably the most appropriate way to deliver the research questions about consumer beliefs and/or behaviors (Neuman, 2003).

In the case of our questionnaires specifically, the information has been collected from the customers who are professionals and managers aged 20-40, all using 4G services with postpaid subscriber registration. Our respondents were clients of the three main service providers at Vietnam's telecommunication market: Vinaphone, Mobifone, and Viettel. The reason for choosing these clients as the interviewees was because all three of these service providers are currently using the same $4 \mathrm{G}$ technology, also because their customer-oriented products are quite similar in many ways. And finally, these are the three major $4 \mathrm{G}$ service providers that cover the majority of the local market. Selection of the postpaid customers as subjects for ous study was predetermined by the fact that post-paid subscribers are those who usually have thoroughly explored the service, thus, they have certain expectations about the quality of service before deciding to register with a provider. The sample consists of the majority of professionals, managers working in the central district of HCM City.

Table 1 - Survey sample structure divided by service providers

(Source: made by the authors)

\begin{tabular}{|c|c|c|c|c|c|}
\hline & VINA & VIETTEL & MOBI & Other Businesses & Total \\
\hline Frequency & 124 & 139 & 51 & 12 & 326 \\
\hline Ratio in \% & 38.04 & 42.64 & 15.64 & 3.68 & 100 \\
\hline
\end{tabular}


Table 2 - Full sociological details on the research sample

(Source: made by the authors)

\begin{tabular}{|c|c|c|c|c|c|c|c|}
\hline № & Features $(n=326)$ & $\begin{array}{c}\text { Number of } \\
\text { people }\end{array}$ & Ratio in $\%$ & № & $\begin{array}{l}\text { Features } \\
(\mathrm{n}=326)\end{array}$ & $\begin{array}{c}\text { Number of } \\
\text { people }\end{array}$ & Ratio in $\%$ \\
\hline & \multicolumn{3}{|c|}{ Gender } & & \multicolumn{3}{|c|}{ Family status } \\
\hline 1 & Male & 158 & 48.47 & 1 & Single & 102 & 33.01 \\
\hline 2 & Female & 168 & 51.53 & 2 & Newly married & 39 & 12.62 \\
\hline & Total & 326 & 100.00 & 3 & Family and children & 144 & 46.60 \\
\hline & \multicolumn{3}{|c|}{ Ages } & 4 & Multiple generations family & 24 & 7.77 \\
\hline 1 & Under 30 & 141 & 43.25 & & Total & 309 & 100.00 \\
\hline 2 & From 30 to 40 & 121 & 37.12 & & \multicolumn{3}{|c|}{ Education } \\
\hline 3 & From 40 to 50 & 38 & 11.66 & 1 & Level 3 or Intermediate & 34 & 10,0 \\
\hline 4 & From 50 to 60 & 9 & 2.76 & 2 & College & 53 & 5,2 \\
\hline 5 & Over 60 & 17 & 5.21 & 3 & University & 195 & 78,0 \\
\hline & Total & 326 & 100.00 & 4 & After university & 19 & 5,6 \\
\hline \multicolumn{4}{|c|}{ Religion } & 5 & Other & 25 & 1,2 \\
\hline 1 & Buddhism & 79 & 24.23 & & Total & 326 & \\
\hline 2 & Catholic & 44 & 13.50 & & \multicolumn{3}{|c|}{ Income } \\
\hline 3 & Protestantism & 24 & 7.36 & 1 & $<5 \mathrm{mln}$ VND & 63 & 19.33 \\
\hline 4 & Islamic & 2 & 0.61 & 2 & 5 to $10 \mathrm{mln} \mathrm{VND}$ & 135 & 41.41 \\
\hline 5 & Other religion & 15 & 4.60 & 3 & 10 to $15 \mathrm{mln} \mathrm{VND}$ & 78 & 23.93 \\
\hline 6 & None of the above & 162 & 49.69 & 4 & Over $15 \mathrm{mln}$ VND & 50 & 15.34 \\
\hline & Total & 326 & 100.00 & & Total & 326 & 100.00 \\
\hline
\end{tabular}

\section{Scale of measurement and measurement model}

Table 3 shows that the Cronbach's Alpha coefficients for all the scales are greater than 0.6 , and the coefficients of variance sum are greater than 0.4 . Therefore, we can state that all the scales can be used in the exploratory factor analysis (EFA). The main method used for data analysis was the comparative statistical method and descriptive statistics via SPSS 23.0 software and using analytical techniques such as scale reliability testing, exploratory analysis ( EFA), confirmatory factor analysis (CFA) and linear structural analysis (SEM) (Nunnally \& Burnstein, 1994). 
FACTORS AFFECTING THE USE OF 4G

Table 3 - Test results on Cranbach's Alpha scales

(Source: made by the authors)

\begin{tabular}{|r|l|c|c|c|}
\hline $\mathrm{N}^{\mathbf{0}}$ & \multicolumn{1}{|c|}{ SCALES } & $\begin{array}{c}\text { Scale } \\
\text { Variances }\end{array}$ & $\begin{array}{c}\text { Cronbach's } \\
\text { Alpha }\end{array}$ & $\begin{array}{c}\text { Cronbach's } \\
\text { Alpha if Item } \\
\text { Deleted }\end{array}$ \\
\hline 1 & Diversity (S1) & 5 & 0.844 & 0.659 \\
\hline 2 & Convenience S2) & 5 & 0.706 & 0.613 \\
\hline 3 & Quality of service (S3) & 3 & 0.866 & 0.751 \\
\hline 4 & Price (S4) & 4 & 0.664 & 0.445 \\
\hline 5 & Value perception (S5) & 3 & 0.808 & 0.470 \\
\hline 6 & Intention to buy (S6) & 3 & 0.740 & 0.526 \\
\hline
\end{tabular}

Table 4 - EFA results for customer perceived value scales

(Source: made by the authors)

\begin{tabular}{|c|c|c|c|c|c|c|}
\hline \multicolumn{7}{|c|}{ Pattern Matrix $^{\mathrm{a}}$} \\
\hline \multirow[b]{2}{*}{ Observed Variables } & \multicolumn{6}{|c|}{ S Component } \\
\hline & S1 & $\mathrm{S} 2$ & S4 & S5 & S3 & S6 \\
\hline $\mathrm{S} 14$ & .982 & & & & & \\
\hline S11 & .976 & & & & & \\
\hline S12 & .973 & & & & & \\
\hline S13 & .969 & & & & & \\
\hline S15 & .968 & & & & & \\
\hline S22 & & .784 & & & & \\
\hline S21 & & .726 & & & & \\
\hline S25 & & .723 & & & & \\
\hline S23 & & .719 & & & & \\
\hline S24 & & .668 & & & & \\
\hline S43 & & & .786 & & & \\
\hline S44 & & & .764 & & & \\
\hline S41 & & & .758 & & & \\
\hline S42 & & & .732 & & & \\
\hline S51 & & & & .943 & & \\
\hline S52 & & & & .942 & & \\
\hline S53 & & & & .741 & & \\
\hline S31 & & & & & .844 & \\
\hline S32 & & & & & .779 & \\
\hline S33 & & & & & .694 & \\
\hline S61 & & & & & & .844 \\
\hline S62 & & & & & & .780 \\
\hline S63 & & & & & & .544 \\
\hline Eigenvalue & 6.288 & 3.149 & 1.991 & 1.664 & 1.622 & 1.437 \\
\hline Variance $(\%)$ & 27.339 & 41.032 & 49.688 & 56.925 & 63.976 & 70.223 \\
\hline Cronbach's Alpha & 0.844 & 0.706 & 0.664 & 0.808 & 0.866 & 0.740 \\
\hline
\end{tabular}


The results of the exploratory factor analysis (Table 4) show that 13 observed variables in the 4 components affect the value of $4 \mathrm{G}$ services. The coefficient $\mathrm{KMO}=0.840$, so EFA is consistent with the Chi-square data and statistics of the Bartlett test with the value of 7480.778 , significance level of 0.000 . Thus, the observed variables are generally correlated. The variance of $70.223 \%$ indicates that the four factors explain $70.223 \%$ of the variance in data while the eigenvalue is 1.437 . The extracted factors are credibility and value.

\section{Multiple regression analysis}

There are 3 regression models that need to be implemented: the first model (single regression) is supposed to determine the effective level of diversity on convenience; the second one (multivariate regression) is expected to determine the important role of each factor of the perceived value. The third model (regressive regression) is to determine the impact of value perception on the purchase intention of the customers. Linear regression results show the R-coefficients of the models are as follows:

- Model 1: $\mathrm{R}^{2}$ is 0.118 and $\mathrm{R}^{2}$ is adjusted to 0.110 , which means that the model explained $11.0 \%$ of the variation in the variable depending on the convenience for customers.

Table 5 - Parameters of each variable in the first regression equation

(Source: made by the authors)

\begin{tabular}{|c|c|c|c|c|c|c|c|c|}
\hline \multicolumn{9}{|c|}{ Coefficients $^{\mathrm{a}}$} \\
\hline \multirow{2}{*}{\multicolumn{2}{|c|}{ Model }} & \multicolumn{2}{|c|}{$\begin{array}{l}\text { Unstandardized } \\
\text { Coefficients }\end{array}$} & \multirow{2}{*}{$\begin{array}{c}\begin{array}{c}\text { Standardized } \\
\text { Coefficients }\end{array} \\
\text { Beta }\end{array}$} & \multirow{2}{*}{$\mathrm{t}$} & \multirow{2}{*}{ Sig. } & \multicolumn{2}{|c|}{ Correlations } \\
\hline & & B & Std. Error & & & & Tolerance & Tolerance \\
\hline \multirow{2}{*}{1} & (Constant) & 2.035 & .247 & & 6.272 & .000 & & \\
\hline & S1 & .469 & .087 & .453 & 3.217 & .000 & 0.860 & 1.009 \\
\hline \multicolumn{3}{|c|}{ a. Dependent Variable: S2 } & & & & & & \\
\hline
\end{tabular}

- Model 2: $\mathrm{R}^{2}$ is 0.604 and $\mathrm{R}^{2}$ is adjusted to 0.589 , which means that the model explained $58.9 \%$ of the variation in the variable depending on the perceived value for the customer. 
FACTORS AFFECTING THE USE OF 4G

Table 6 - Parameters of each variable in the second regression equation

(Source: made by the authors)

\begin{tabular}{|c|c|c|c|c|c|c|c|c|}
\hline & \multirow[t]{2}{*}{ Model } & \multicolumn{2}{|c|}{$\begin{array}{l}\text { Unstandardized } \\
\text { Coefficients }\end{array}$} & \multirow{2}{*}{$\begin{array}{c}\text { Standardized } \\
\text { Coefficients }\end{array}$} & \multirow[t]{2}{*}{$\mathrm{t}$} & \multirow[t]{2}{*}{ Sig. } & \multicolumn{2}{|c|}{$\begin{array}{l}\text { Collinearity } \\
\text { Statistics }\end{array}$} \\
\hline & & B & Std. Error & & & & Tolerance & VIF \\
\hline \multirow{5}{*}{1} & (Constant) & -.463 & .342 & & -1.124 & .165 & & \\
\hline & $\mathrm{S} 1$ & .252 & .063 & .268 & 4.283 & .000 & .877 & 1.020 \\
\hline & $\mathrm{S} 2$ & .256 & .065 & .272 & 3.492 & .000 & .875 & 1.243 \\
\hline & S3 & .169 & .047 & .199 & 3.225 & .003 & .954 & 1.242 \\
\hline & S4 & .504 & .053 & .532 & 8.734 & .000 & .947 & 1.126 \\
\hline
\end{tabular}

- Model 3: $\mathrm{R}^{2}$ is 0.415 and $\mathrm{R}^{2}$ is adjusted to 0.410 , which means that the model explained $41.0 \%$ of the variation in the variable depending on the purchase intention of customers.

Table 7 - Parameters of each variable in the third regression equation

(Source: made by the authors)

\begin{tabular}{|c|c|c|c|c|c|c|c|c|}
\hline \multicolumn{9}{|c|}{ Coefficients $^{\mathrm{a}}$} \\
\hline & \multirow{2}{*}{ Model } & \multicolumn{2}{|c|}{$\begin{array}{l}\text { Unstandardized } \\
\text { Coefficients }\end{array}$} & \multirow{2}{*}{$\begin{array}{c}\begin{array}{c}\text { Standardized } \\
\text { Coefficients }\end{array} \\
\text { Beta }\end{array}$} & \multirow[t]{2}{*}{$\mathrm{t}$} & \multirow{2}{*}{ Sig. } & \multicolumn{2}{|c|}{ Collinearity Statistics } \\
\hline & & B & Std. Error & & & & & B \\
\hline \multirow[t]{2}{*}{1} & (Constant) & .663 & .329 & & 2.013 & .047 & & \\
\hline & S5 & .779 & .089 & .624 & 8.795 & .000 & .850 & 1.012 \\
\hline & ependent V & le: S6 & & & & & & \\
\hline
\end{tabular}

\section{The results of testing the theoretical model}

From the above analysis, it can be concluded that the theoretical model is fully suitable for our research data and all our initial hypotheses -- H1, H2, H3, H4, H5, and H6 -- are confirmed.

H1 (the variance explaining $11 \%$ of the data), H5 and H6 (41.0\% explaining the intent to purchase) are strongly supported. $\mathrm{H} 2, \mathrm{H} 3$, and $\mathrm{H} 4$ are also supported. Diversity, convenience, quality of service and price together shape a larger part (58.9\%) of the perceived value.

In the differential analysis, gender variables, age, monthly spending on telephone bills, phone usage and subscription to $4 \mathrm{G}$ services are now included in the model. However, their effect on buying intent is negligible. The effect of IT on efficiency for both purchase intent 
and value added was found to be negligible and efficacy could be random, thus resulting in the overall negligible effects.

\section{Structural Equation Model Results}

The table below shows the results for fit of both structures, including customer behavior and purchase intentions of clients, and the texture models for the two sets of data. Chi-square (X2) is used in this study to examine the existence of the relationships among variables in the model (Hair et al., 2006). The AMOS output is presented in Table 7 which shows that the models are equipped with good data, therefore, the proposed model is appropriate in explaining relationship between the variables.

Table 8 - Results of the AMOS analysis

(Source: made by the authors)

\begin{tabular}{|c|c|c|c|c|c|c|c|c|c|c|}
\hline & & & & Goodness of $f$ & Measures & & & & & \\
\hline Model & $\mathrm{X} 2$ & Df & $\mathrm{p}$ & $\begin{array}{c}\text { X2/df } \\
(\mathrm{CMIN} / \mathrm{DF})\end{array}$ & RMSEA & NFI & RFI & IFI & TLI & CFI \\
\hline Sample & 413.893 & 214 & 0.000 & 1.934 & .052 & .936 & .946 & .973 & .968 & .973 \\
\hline Criteria & $\begin{array}{c}\mathrm{P}>.05 \\
\text { (non-sig }\end{array}$ & $\geq 0$ & - & 2 to 3 & $<.08$ & $>.90$ & $>.90$ & $>.90$ & $>.90$ & $>.90$ \\
\hline
\end{tabular}

Note: $\mathrm{X}^{2}=$ Chi-square test, $\mathrm{df}=$ Degrees of freedom, RMSEA = Root mean square error of approximation, NFI $=$ Normed Fit Index, RFI $=$ Relative Fit Index, IFI $=$ Incremental Fit Index, TLI $=$ Tucker-Lewis Index, CFI $=$ Comparative Fit Index.

The results show that this model valuable chi-squared statistics are 413.893 with 214 degrees of freedom $(\mathrm{p}=0.000)$. Chi-squared relative degrees of freedom accordingly CMIN/DF was $1.934(<2)$. Other indicators are GLI = $0.910(>0.9)$, TLI $=0.968(>0.9)$, CFI $=0.973(>0.9)$ and RMSEA $=0.052(<0.08)$. Therefore, this model achieved compatibility with the data already collected. 


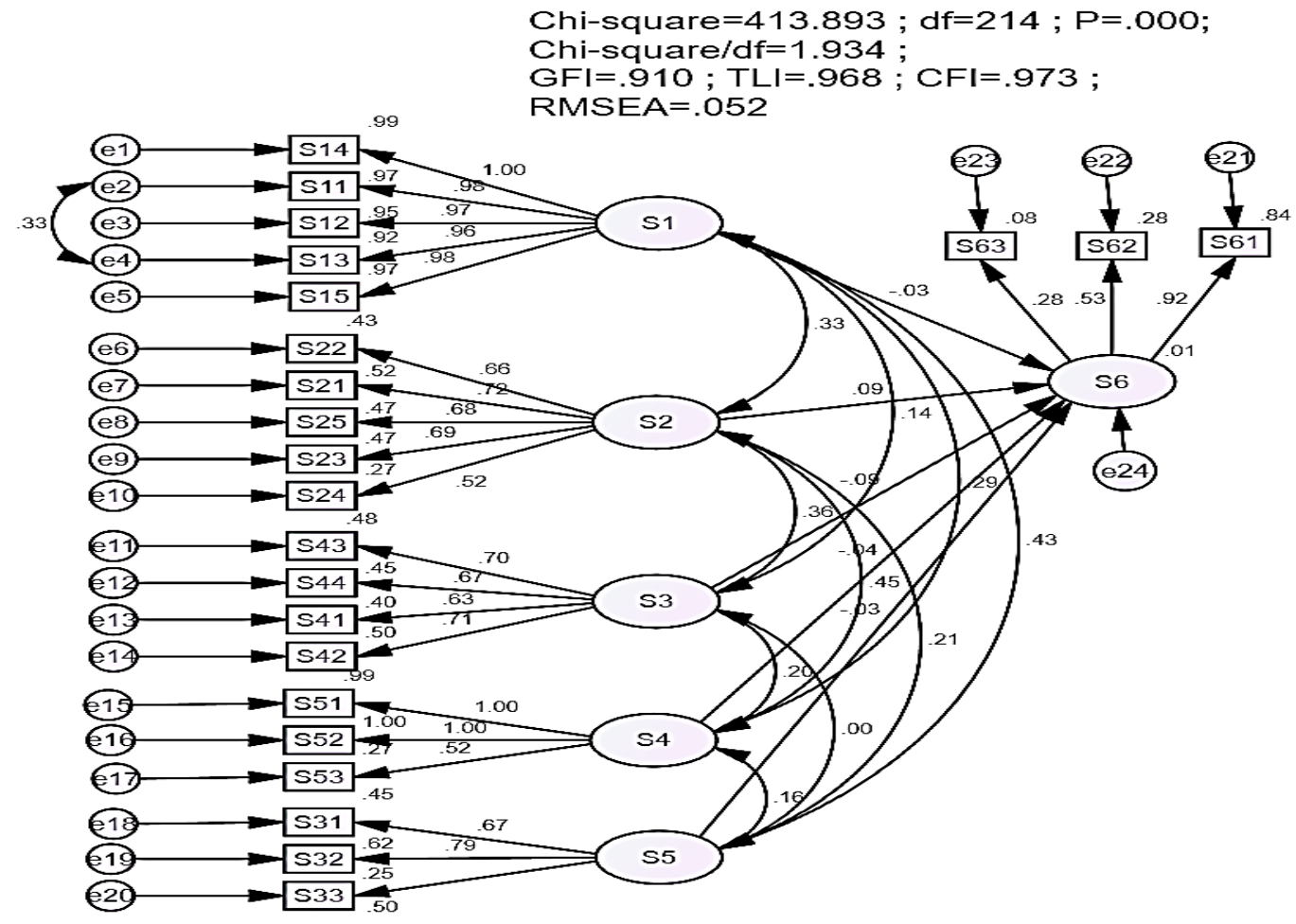

Figure 1- SEM results

(Source: made by the authors)

\section{Testing the reliability of estimates by means of bootstrap}

The bootstrap method is usually used to test the model estimates, with the pattern repeat being $\mathrm{N}=1000$. The estimation results for 1000 samples averaged together with the deviations are presented in Table 8 . CR has very small absolute value, thus, it can be stated that the deviation is very small; while not statistically significant at the $95 \%$ confidence level. Thus, we can conclude that the model estimates can be trusted.

Table 9 - Results estimated by bootstrap, $\mathrm{N}=1000$.

(Source: made by the authors)

Estimate standard

Estimate Bootstrap with

values $\mathrm{N}=1000$

\begin{tabular}{|c|c|c|c|c|c|c|c|c|c|}
\hline \multicolumn{3}{|c|}{ Parameter } & Estimate & SE & SE-SE & Mean & Bias & SE-Bias & $\mathrm{CR}$ \\
\hline S6 & $<--$ & S1 & 0.023 & 0.057 & 0.001 & -0.022 & 0.001 & 0.002 & 2 \\
\hline S6 & $<--$ & S2 & 0.106 & 0.105 & 0.002 & 0.096 & -0.01 & 0.003 & -0.3 \\
\hline S6 & $<--$ & S5 & 0.034 & 0.092 & 0.002 & -0.038 & -0.004 & 0.003 & -0.75 \\
\hline S6 & $<---$ & S3 & 0.115 & 0.099 & 0.002 & -0.117 & -0.002 & 0.003 & -1.5 \\
\hline S6 & $<--$ & S4 & 0.032 & 0.055 & 0.001 & -0.025 & 0.007 & 0.002 & 0.29 \\
\hline
\end{tabular}




\section{Discussion and implications}

The focus of this study has been on identifying the key variables that significantly influence the business success of 4G services' provision. The expected variety of service, convenience, and quality of service -- all contribute to the benefit components of value perception, and they also contribute to the cost components of value perception. Finally, the expected perceived value has a positive influence on the intention to buy.

The answers demonstrate that the monetary value is the most important element of value perception, followed by convenience and quality of support. Price is found to have a significant negative impact on cognitive value. The highest average score (3.9 out of 5) indicates that most customers feel that $4 \mathrm{G}$ services are too expensive for them. Price can thus be considered as one of the most important factors in the widespread adoption of $4 \mathrm{G}$ services.

Saving of time and effort (aka Convenience) provided by $4 \mathrm{G}$ service is also found to have a significant impact on value. The impact of service quality is lower because many respondents may not really evaluate various aspects of service provision if not actually subscribed to $4 \mathrm{G}$ services. Another important finding is that the effect of many types of services on value perception is negligible. This implies that merely providing a large variety of services does not attract many new users. In fact, users may find themselves overwhelmed by the amount of services provided, especially when they do not really need so many of them. Nevertheless, diversity of services has its potential influence on convenience, hence sustaining a positive effect on value. This means that while many types of inspection and repairs may not instantly contribute to perceived value, convenience, mainly due to time savings and service delivery effort, contribute to increased value perception.

\section{Conclusions, limitations and recommendations}

This study has several implications. First, this empirical research contributes real-life data on the acceptance of $4 \mathrm{G}$ service according to the Zeithaml value model (1988). Factors such as convenience and quality of service add to the beneficial aspects of value perception, while prices add to its cost aspect. Secondly, value perception is found to be a significant predictor of buying intention. This means that a consumer who has determined a solid value in a product/service is likely to buy/accept it more easily. Finally, diversity of services has been found to not that directly affect the perceived value, as it is mostly mediated by convenience.

One of our key conclusions is that rather than simply offering a large number of services, it is much more important to link the top convenience services with the key goal to save time and efforts. Finally, prices in many cases have been reduced to make $4 \mathrm{G}$ services more attractive, thus boosting their development further.

However, due to limited time and costs of this research, there are certain other limitations as well. The sample size of the pilot data was quite small (28 valid samples out of 


\section{FACTORS AFFECTING THE USE OF 4G}

30 collected) and the final sample was also quite small (326 participants). Secondly, this research study has been limited to professionals working in the central business district of the HCM City. Thus, the sample could also be expanded in number and also in terms of representation. Also, other countries where $4 \mathrm{G}$ services are already available at the market can be also considered for the sake of further comparison of the results obtained.

Generally speaking, this research suggests that price, convenience, quality of service, diversity in the service offer are needed to sense the value from a service. The relationship between service diversity and value perception are mediated by convenience. In other words, our research suggests that value perception has a solid direct relation with the intention to purchase.

Future research studies in the same direction can be expanded onto different samples in other districts in Ho Chi Minh City. Similar studies can be also carried out in rural areas as long as $4 \mathrm{G}$ services are already introduced there.

The study can be also interestingly expanded to include other factors of influence, such as demand for $4 \mathrm{G}$ services, their availability locally, enjoyment from using and so on. All of these factors, together or alone, may affect the intention to buy. Same logic can be also applied to study the application of the technologies other than $4 \mathrm{G}$.

\section{References:}

Anderson, J.C. \& Gerbing, D.W. (1998). Structural equation modeling in practice: A review and recommended two-step approach. Psychological Bulletin, 103:3. 411-423.

Auger, P. \& Gallaugher, J. M. (1997). Factors Affecting the Adoption of an Internet-Based Sales Presence for Small Business. The Information Society (13). 55-74.

Berry, L.L., Seiders, K. \& Grewal, D. (2002). Understanding service convenience. Journal of Marketing, 66:3. 1-17.

Hair, J.F., Anderson, R.E., Tatham, R.L. \& Black, W.C. (1995). Multivariate Data Analysis with Reading, 4th Edition, Englewood Cliffs, NJ: Prentice Hall.

Kahneman, D. \& Tversky, A. (1984). Choices, values and frames. American Psychologist,39. 341350.

Ng-Kruelle, G., Swatman, P A., Rebne, D.S. \& Hampe, J.F. (2002). The Price of Convenience, Quarterly Journal of Electronic Commerce, 3:3. 273.

Parasuraman, A., Berry, L.L. \& Zeithaml, V.A. (1998). SERVQUAL: A multiple-item scale formeasuring customer perceptions of service quality, Journal of Retailing, 64:1, 1988. 12-40.

Zeithaml, V. A. (1988). Consumer Perceptions of Price, Quality, and Value: A Means-End Model and Synthesis of Evidence. Journal of Marketing, 52:3. 2-22.

Paper submitted

Paper accepted for publishing

Paper published online
21 September 2018

01 December 2018

31 January 2019 